\title{
Alleviation of salinity stress on in vitro propagation ability of Populus alba L. using Iron Nano particles
}

\author{
Nora M. Youssef, Nahed G. Abdel Aziz and Awatef I.A.R. Ali
}

Ornamental plant and Woody trees Dept., Agricultural and Biological Res. Division, National Research Centre (NRC), Egypt.

Received: 15 Oct. 2019 / Accepted 12 Nov. 2019/ Publication date: 20 Nov. 2019

\begin{abstract}
This work was conducted to examine the in vitro propagation (shooting and rooting) behavior of Populus alba $\mathrm{L}$. via culturing the nodal explants under different concentrations of $\mathrm{NaCl}(0.0,1000$, $2000,4000,8000 \mathrm{ppm}$ ) and alleviating salinity stress on in vitro shooting and rooting ability using two concentrations $(5.0$ and $10.0 \mathrm{mg} / \mathrm{l})$ of Nanoparticles of Ferric Oxide $\left(\mathrm{Fe}_{2} \mathrm{O}_{3} \mathrm{NPs}\right)$ added to MS culture medium. The results showed that the highest number of shootlets per explant, number of leaves and number of roots per shootlet of Populus alba plant were observed for control (salt-free MS culture medium). All concentrations of $\mathrm{NaCl}$ (2000 to $8000 \mathrm{ppm})$ led to decreasing of rooting percentage. Supplementation of $\mathrm{Fe}_{2} \mathrm{O}_{3}$ NPs at $10 \mathrm{mg} / 1$ with 2000 ppm salinity to MS culture medium had significant promotion effect on in vitro shooting parameters compared with other treatments. The maximum chlorophyll a and $\mathrm{b}$ contents were observed from control plants while, the highest carotenoids content was observed when the explants were cultured on $2000 \mathrm{ppm}$ salinity. Addition of $\mathrm{Fe}_{2} \mathrm{O}_{3}$ NPs to culture medium led to an increase in the content of chlorophyll $\mathrm{a}, \mathrm{b}$ and carotenoids compared with using $\mathrm{NaCl}$ alone. Using $\mathrm{Fe}_{2} \mathrm{O}_{3} \mathrm{NPs}$ at $5 \mathrm{mg} / 1$ that were added to MS culture medium under salinity $2000 \mathrm{ppm}$ promoted both chlorophyll (a) and (b) contents while, the maximum content of carotenoids was observed from plants treated with 2000 ppm salinity combined with $\mathrm{Fe}_{2} \mathrm{O}_{3} \mathrm{NPs}$ at $10 \mathrm{mg} / \mathrm{l}$. Increasing the concentration of salinity in culture medium led to increase of proline content. Using $\mathrm{Fe}_{2} \mathrm{O}_{3}$ NPs at all salinity levels reduced the proline content compared with using $\mathrm{NaCl}$ alone. The highest reduction of proline content was obtained at $1000 \mathrm{ppm}$ of $\mathrm{NaCl}$ plus $\mathrm{Fe}_{2} \mathrm{O}_{3} \mathrm{NPs}$ at 5 or 10 $\mathrm{mg} / \mathrm{l}$ treatments compared with other treatments.
\end{abstract}

Keywords: Populus alba L., in vitro propagation, salinity and $\mathrm{Fe}_{2} \mathrm{O}_{3} \mathrm{NPs}$

\section{Introduction}

Populus alba, (White Poplar) is a tree species that is widely spread throughout eastern Asia, Europe and Northern Africa. In spite of its high adaptation, it is considered to be a threatened species and an indicator of biodiversity (Kovacevic et al., 2010a). This species has a wide usage in landscaping and horticulture, particularly the genotypes with a pyramidal tree shape, its use for wood and biomass production (Kovacevic et al., 2010b).

White poplar (Populus alba) is one of the most interesting model tree species in biotechnology. The trees grow rapidly and make significant gains with low farming costs and service operations. Tissue culture is an effective method to predicting the possibility of growing poplar trees under different salinity conditions and it's an important propagation technique (Confalonieria et al., 2000). It is known that different genotypes of the same species differ in their requirements. Thus, it is necessary to know the tolerability of white poplar trees for salinity stress. In vitro culture constitutes a useful tool for rapidly and economically evaluating of the plant's tolerance to salt stress, especially for tree species that have long reproductive cycles. Shoots are easy to propagate in vitro and plant material selected from drought or salt stressed cultures can be used to establish plantations in dry or saline soils (Cano et al., 1998).

Salt stress in arid or semi-arid zones is one of the main stresses that can badly limit plant growth and productivity (Koca et al., 2007). The decreasing in the plants growth under salt stress may happen by effects of specific ions on metabolic processes ranging from the absorption of nutrients to enzyme inhibition or activation or an osmotic stress due to reducing of the external water potential (Carvajal et

Corresponding Author: Nora M. Youssef, Ornamental plant and Woody trees Dept., Agricultural and Biological Res. Division, National Research Centre (NRC), Egypt.

E-mail: norayousif20@yahoo.com 
al., 2000). The salt tolerance mechanisms include ion regulation and osmoregulation that can be occurred by accumulation of several compatible solutes by the salt stressed plants (Karley et al., 2000; Vera-Estrella et al., 2004).

Iron is a necessary element for plant metabolism. It works as a cofactor for several enzymes involved in redox reaction such as photosynthesis, hormone synthesis, respiration as well DNA synthesis (Barberon et al., 2011). According to Fageria (1990), although iron element is a popular on the earth's crust but sometimes it becomes restrict factor in agricultural production especially under arid or semi-arid calcareous soils. Iron is also essential for biosynthesis of chlorophyll (Waruma Jinadasa, 2013). Nanotechnology plays a necessary role in agriculture and food production which provide to microparticles new features and special applications. Iron oxide nanoparticles have diverse applications in medicine and biotechnology, according to Mahmoudi et al., (2009).

The objectives of this study were to evaluate the response of Populus alba plant to proliferate under different salinity levels and examine the effect of $\mathrm{Fe}_{2} \mathrm{O}_{3} \mathrm{NPs}$ to improve its salinity tolerance ability in vitro.

\section{Materials and Methods}

The experimental study was conducted at Tissue Culture Technique Lab., Central laboratories, Department of Ornamental Plants and Woody Trees, National Research Centre (NRC), Egypt to examine the in vitro growth ability of plant under different salinity levels during years 2017 and 2018 on Populus alba L.

The explants were taken from 2 years old seedlings in nursery of Timber Trees Dept., Hort. Res. Inst., Agriculture Research Center, Egypt.

The shoot tips explants were washed in soapy water using septol soap with shaking for 20 min., then washed with running tap water for one hour. The explants were then immersed in different solutions under aseptic conditions in a laminar air-flow cabinet as follows: $70 \%(\mathrm{v} / \mathrm{v})$ commercial ethanol for $30 \mathrm{sec}$., Clorox ( $\mathrm{NaOCl}, 5.25 \%$ free chlorine) at concentrations of $15 \%$ (v/v) for $10 \mathrm{~min}$., mercuric chloride (MC) at concentrations of $0.2(\mathrm{w} / \mathrm{v})$ for $5 \mathrm{~min}$. The explants were rinsed three times with sterile distilled water after each disinfection treatment.

\section{Culture media}

The explants were cultured on a basal MS medium (Murashige and Skoog, 1962) supplemented with sucrose at $25 \mathrm{~g} / \mathrm{l}, 0.2 \mathrm{mg} / \mathrm{l}$ of benzlaminopurine (BAP) and indole- 3- butyric acid at $0.1 \mathrm{mg} / \mathrm{l}$. MS culture medium was solidified by the addition of $0.7 \%$ agar prior to autoclaving at $1.2 \mathrm{~kg} / \mathrm{cm} 2$ for $15 \mathrm{~min}$. The $\mathrm{pH}$ of the culture medium was adjusted to 5.8 . Culturing was done in 200 $\mathrm{ml}$ glass jars containing $25 \mathrm{ml}$ of the medium.

\section{Incubation condition}

Cultures were incubated under controlled conditions in the growth chamber. The incubation temperature was $24 \pm 2^{\circ} \mathrm{C}$ controlled by a "Power" air conditioner. The photoperiod was 16 hours light/8hour darkness, controlled automatically. Illumination intensity was 3000 lux from cool fluorescent lamps.

\section{Experiment procedure}

The in vitro growth (shooting and rooting) behavior was examined through culturing the nodal explants which were obtained from proliferation medium under different concentrations of $\mathrm{NaCl}(0.0$, $1000,2000,4000,8000$ ppm).

For shooting and rooting ability improvement, explants were cultured on MS media containing two concentrations (5.0 and $10.0 \mathrm{mg} / \mathrm{l})$ of Nanoparticles of Ferric Oxide $\left(\mathrm{Fe}_{2} \mathrm{O}_{3} \mathrm{NPs}\right) \mathrm{MS}$ culture medium.

Each treatment consisted of five replicates (jars) with five explant per jar. After eight weeks of treatments for each experiment, number and length of shootlets, rooting percent as well as roots number and lengths were recorded. 


\section{Specification of used Nanoparticles in the experiment}

\section{1- Nano- Iron Oxide}

Specification

\begin{tabular}{lcc}
\hline Phase & hematite & XRD \\
\hline Particle size & $<50 \mathrm{~nm}$ & TEM \\
Surface area & $>50 \mathrm{~m}^{2} / \mathrm{gm}$ & BET (P/Po: up to 0.35 \\
\hline
\end{tabular}

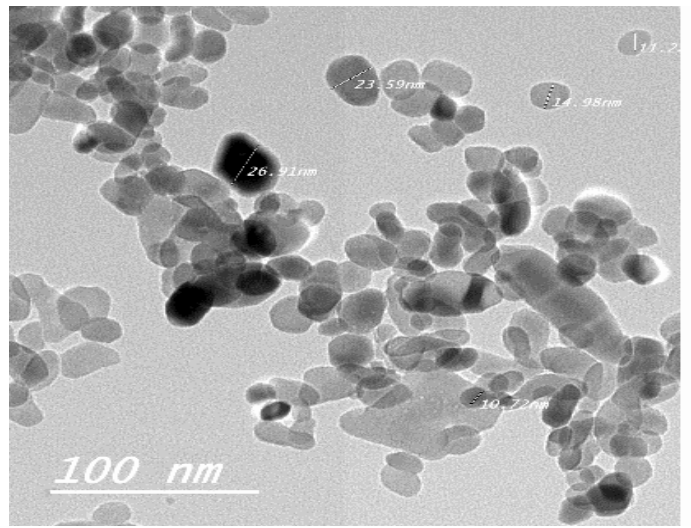

Scanning electron microscopy image of Nano- Iron oxide

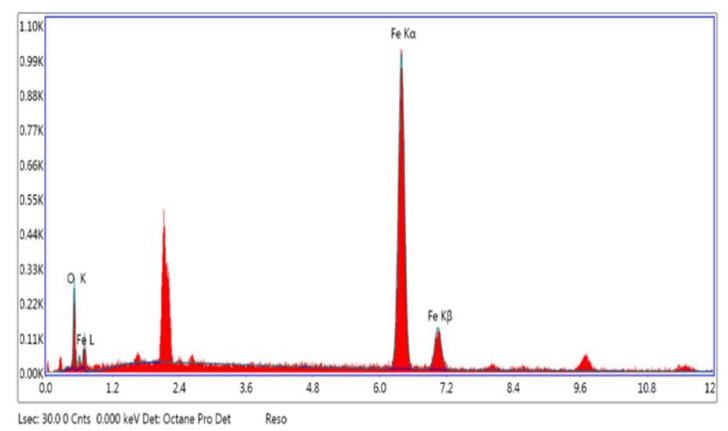

\section{XRD peak pattern for Nano- Iron oxide}

\section{Chemical analysis}

\section{Photosynthetic pigments}

Photosynthetic pigments (chlorophyll a and b) as well as carotenoids were determined in shootlets tissues as $\mathrm{mg} / 100 \mathrm{~g}$ fresh weight using spectrophotometer, according to the procedure achieved by Yang et al. (1967).

\section{Proline determination}

The proline was determined according to Carrilo et al., (2011). $500 \mu 1$ ethanolic extract $(80 \%$ ethanol) or $100 \mu 1$ of 5-2-1-0.5-0.2 mM proline standard completed with up to $400 \mu 1$ of ethanol: water $(40: 60 \mathrm{v} / \mathrm{v})$ is added to $1 \mathrm{ml}$ of reaction mixture (ninhydrin $1 \%(\mathrm{w} / \mathrm{v})$ in acetic acid $60 \%(\mathrm{v} / \mathrm{v})$, ethanol $20 \%(\mathrm{v} / \mathrm{v}))$ and incubated at $95^{\circ} \mathrm{C}$ for $20 \mathrm{~min}$. After that, the mixture was cooled at room temperature and centrifuged $1 \mathrm{~min}$ at $10000 \mathrm{rpm}$. the supernatant was read at $520 \mathrm{~nm}$ with uv-spectrophotometer.

Proline in nmol.mg ${ }^{-1}$ F.W. or in $\mu$ mol.g- ${ }^{1}$ F.W. $=$ (Absextract - blank) /slope *Volextract/Volaliquot*1/F.W.

\section{Statistical layout}

The average of data recorded for different parameters statistically analyzed using randomized complete block design with three replicates per treatment. The treatments means were compared for 
significance by Duncan's New Multiple Range test at $0.05 \%$ level of probability (Duncan, 1955) using COSTATV-63.

\section{Results and Discussion}

\section{In vitro propagation behavior}

The present experiment indicated that the number of shootlets per explant, number of leaves and number of roots per shootlet of Populus alba plant were observed for the control tested (salt-free MS culture medium) that were greatest $(2.44,22.44$ and 1.55 , respectively) in comparison with those grown on different concentrations of $\mathrm{NaCl}$ (Table 1). Increasing concentrations of $\mathrm{NaCl}$ under study in MS culture medium led to decreasing in the length of shootlets except the concentration $1000 \mathrm{ppm}$ of salinity which significantly increased the length of shootlets $(35.33 \mathrm{~mm})$, but had an inhibitory effect on length of roots as shown in table (1). All concentrations of $\mathrm{NaCl}$ (1000 to $8000 \mathrm{ppm})$ led to an inhibition effect on rooting percentage. The damage of tissues, shoots in plants can be caused by the excessive accumulation of $\mathrm{Na}+$ and $\mathrm{Cl}$ - ions, (Kuciakowski et al., 1997). Siler et al. (2007) found that the first plant organs affected and most sensitive are roots by salt stress. These results agree with Wahome et al. (2001) and Fathy et al. (2019).

Table 1: In vitro propagation behavior of Populus alba under effect of various salinity levels.

\begin{tabular}{|c|c|c|c|c|c|c|}
\hline $\begin{array}{l}\text { Characters } \\
\text { Salinity (ppm) }\end{array}$ & $\begin{array}{l}\text { Number of } \\
\text { shootlet } \\
\text { /explant }\end{array}$ & $\begin{array}{l}\text { length of } \\
\text { Shootlet } \\
\text { (mm.) }\end{array}$ & $\begin{array}{c}\text { Number of } \\
\text { leaves/ } \\
\text { shootlet }\end{array}$ & $\begin{array}{c}\text { Rooting } \\
(\%)\end{array}$ & $\begin{array}{l}\text { Number of } \\
\text { roots/ } \\
\text { shootlet }\end{array}$ & $\begin{array}{l}\text { Length of } \\
\text { roots }(\mathrm{mm} .)\end{array}$ \\
\hline 0.0 (Control) & $2.44^{\mathrm{a}}$ & $21.67^{b}$ & $22.44^{\mathrm{a}}$ & $71.33^{\mathrm{a}}$ & $1.55^{\mathrm{a}}$ & $19.00^{\mathrm{a}}$ \\
\hline 1000 (1g/l NaCl) & $2.22^{\mathrm{ab}}$ & $35.33^{\mathrm{a}}$ & $14.22^{\mathrm{b}}$ & $22.00^{\mathrm{b}}$ & $0.83^{b}$ & $38.33^{\mathrm{ab}}$ \\
\hline $2000(2 \mathrm{~g} / \mathrm{l} \mathrm{NaCl})$ & $1.78^{\mathrm{bc}}$ & $16.67^{\mathrm{c}}$ & $12.78^{\mathrm{b}}$ & 0 & 0 & 0 \\
\hline $4000(4 \mathrm{~g} / \mathrm{l} \mathrm{NaCl})$ & $1.67^{\mathrm{bc}}$ & $10.83^{\mathrm{d}}$ & $12.22^{\mathrm{b}}$ & 0 & 0 & 0 \\
\hline $8000(8 \mathrm{~g} / \mathrm{l} \mathrm{NaCl})$ & $1.06^{\mathrm{c}}$ & $7.83^{\mathrm{e}}$ & $4.66^{\mathrm{c}}$ & 0 & 0 & 0 \\
\hline
\end{tabular}

Means within a column having the same letters are not significantly different according to Duncan's Multiple Range Test (DMRT) at 5\% level.

Data in Table (2) show the effect of Nanoparticles of Ferric Oxide $\left(\mathrm{Fe}_{2} \mathrm{O}_{3} \mathrm{NPs}\right)$ on in vitro propagation behavior of Populus alba plants under salinity stress. Addition of $\mathrm{Fe}_{2} \mathrm{O}_{3}$ NPs at $10 \mathrm{mg} / 1$ with $2000 \mathrm{ppm}$ salinity to MS culture medium significantly increased the shootlet number, shootlet length, leaves number and roots number $(7.67,30.27 \mathrm{~mm}, 42.67$ and 2.0 respectively) as compared to the control or any other treatments. While, the control treatment gave the highest values of rooting percentage and roots length $(71.33 \%$ and $24.0 \mathrm{~mm}$, respectively) compared with other treatments. Improvements in plant growth attributes in present study are in agreement with the findings of Jamzed et al., (2013), Jalali and Zargani (2014), Amirnia et al. (2014) and Saeedi et al. (2016) who reported significant growth parameters improvements by adding Fe-Nano particles.

Table 2: Effect of $\mathrm{Fe}_{2} \mathrm{O}_{3}$ NPs on alleviation of salinity stress on in vitro propagation of Populus alba.

\begin{tabular}{ccccccc}
\hline Character & $\begin{array}{c}\text { Number of } \\
\text { shootlet } \\
\text { /explant }\end{array}$ & $\begin{array}{c}\text { Length of } \\
\text { Shootlet } \\
\text { Treatments }\end{array}$ & $\begin{array}{c}\text { Number of } \\
\text { leaves/ } \\
\text { shootlet }\end{array}$ & $\begin{array}{c}\text { Rooting } \\
\mathbf{( \% )}\end{array}$ & $\begin{array}{c}\text { Number of } \\
\text { roots } \\
\text { /shootlet }\end{array}$ & $\begin{array}{c}\text { Length of } \\
\text { roots }(\mathbf{m m} \text {.) }\end{array}$ \\
\hline $\mathbf{0 . 0}$ & $2.44 \mathrm{~d}$ & $21.67 \mathrm{~b}$ & $22.44 \mathrm{~cd}$ & $71.33 \mathrm{a}$ & $1.55 \mathrm{ab}$ & $19.00 \mathrm{a}$ \\
$\mathbf{S}+\mathbf{N F e 1}$ & $3.67 \mathrm{~cd}$ & $23.61 \mathrm{~b}$ & $18.67 \mathrm{~d}$ & $22.0 \mathrm{bcd}$ & $0.67 \mathrm{~cd}$ & $12.33 \mathrm{ab}$ \\
$\mathbf{S 1 + N F e 2}$ & $4.63 \mathrm{c}$ & $17.92 \mathrm{c}$ & $26.00 \mathrm{c}$ & 0 & 0 & 0 \\
$\mathbf{S}+\mathbf{N F e 1}$ & $6.00 \mathrm{~b}$ & $17.32 \mathrm{~d}$ & $24.33 \mathrm{c}$ & $33.33 \mathrm{bc}$ & $0.83 \mathrm{bc}$ & $21.67 \mathrm{a}$ \\
$\mathbf{S 2}+\mathbf{N F e 2}$ & $7.67 \mathrm{a}$ & $30.27 \mathrm{a}$ & $42.67 \mathrm{a}$ & $44.33 \mathrm{ab}$ & $2.00 \mathrm{a}$ & $24.00 \mathrm{a}$ \\
$\mathbf{S 3}+\mathbf{N F e 1}$ & $3.33 \mathrm{~cd}$ & $10.89 \mathrm{~d}$ & $14.00 \mathrm{e}$ & 0 & 0 & 0 \\
$\mathbf{S 3 + N F e 2}$ & $3.00 \mathrm{~cd}$ & $13.22 \mathrm{~d}$ & $19.33 \mathrm{~d}$ & $11.00 \mathrm{~cd}$ & $0.33 \mathrm{~cd}$ & $3.33 \mathrm{~b}$ \\
$\mathbf{S 4}+\mathbf{N F e 1}$ & $3.33 \mathrm{~cd}$ & $12.53 \mathrm{~d}$ & $25.00 \mathrm{c}$ & 0 & 0 & 0 \\
$\mathbf{S 4}+\mathbf{N F e 2}$ & $3.00 \mathrm{~cd}$ & $18.11 \mathrm{c}$ & $31.67 \mathrm{~b}$ & 0 & 0 & 0 \\
\hline
\end{tabular}

Means within a column having the same letters are not significantly different according to Duncan's Multiple Range Test (DMRT) at 5\% level.

S1: Salinity (1000 ppm), S2: Salinity (2000 ppm), S3: Salinity (4000 ppm) and S4: Salinity (8000 ppm). NFe1: Fe $\mathrm{O}_{3} \mathrm{NPs}$ $(5 \mathrm{mg} / 1), \mathrm{NFe} 2: \mathrm{Fe}_{2} \mathrm{O}_{3} \mathrm{NPs}(10 \mathrm{mg} / 1)$. 


\section{Chemical constituents}

The presented results in Fig. (1) show the effect of salinity treatments on chlorophyll a, b and carotenoids contents of Populus alba. Salinity had a remarkable effect on chlorophyll content. Control plants contained the highest chlorophyll a and b contents which reached to 95.7 and $64.72 \mathrm{mg} / 100 \mathrm{~g}$ F.W. compared to all salinity treatments. The reduction was greater at the highest salinity level $(8000$ ppm). While, control and $2000 \mathrm{ppm}$ of $\mathrm{NaCl}$ gave the maximum carotenoids contents $(60.22$ and $64.29 \mathrm{mg} / 100 \mathrm{~g}$ F.W., respectively) compared with other treatments. Similar responses were previously observed in other trees, high salinity caused a decrease in chlorophyll content of moringa oliefera (El- Sayed et al., 2013) and reduction in concentration of Eucalyptus camadulensis (Rawat and Banerjee, 1998).

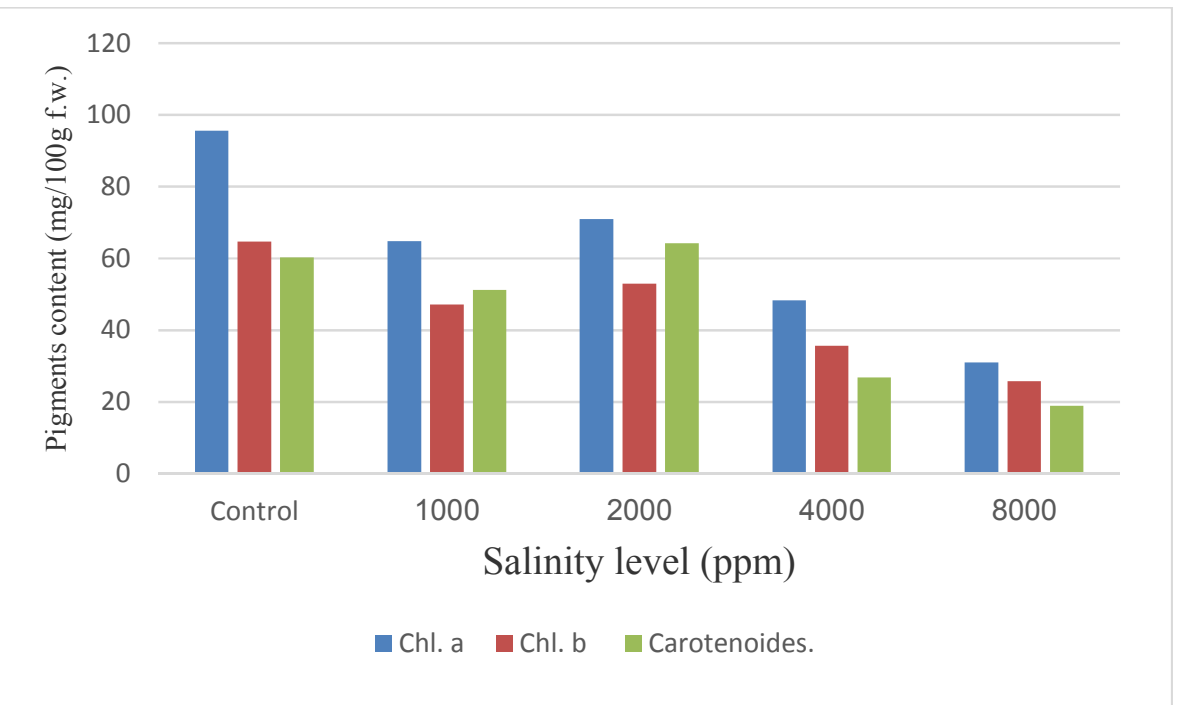

Fig. 1: Photosynthetic pigments content in Populus alba plantlets effecting by different salinity levels.

Data in Fig. (2) found that the effect of different levels of $\mathrm{NaCl}$ plus $\mathrm{Fe}_{2} \mathrm{O}_{3}$ NPs on pigments content followed the same trend of salinity treatments without using $\mathrm{Fe}_{2} \mathrm{O}_{3}$ NPs. But, addition $\mathrm{Fe}_{2} \mathrm{O}_{3}$ NPs led to increases in the content of chlorophyll $a, b$ and carotenoids, compared with using $\mathrm{NaCl}$ alone. The maximum reduction in values of pigments content was obtained with the highest salinity level $(8000 \mathrm{ppm})$ with $\mathrm{Fe}_{2} \mathrm{O}_{3} \mathrm{NPs}$ at $10 \mathrm{mg} / \mathrm{l}$ compared with other treatments. The decreasing of chlorophyll content in shoots would decrease the photosynthesis by reducing light absorption (Sivanesan et al., 2008). The changes in leaf chlorophyll content may have been by reduction biosynthesis or increased degradation of chlorophyll under saline conditions. Furthermore, in salt stressed plants, breakdown of ultra-structure of chloroplasts including plastid envelop, thylakoids (Santos, 1998).

The data in Fig (3) show the response of amino acid (proline) in the leaves of poplar to salinity levels. The content of proline ranged between 0.151 and $0.451 \mathrm{nmol} / \mathrm{mg}$. All salinity treatments increased the content of proline as compared to control. The proline content reached to maximum value $(0.451 \mathrm{nmol} / \mathrm{mg})$ at the highest level of salinity $(8000 \mathrm{ppm})$ compared with other levels. Similar conclusion was also reported by Farahat (1990) on Myoporum acuminatum.

Concerning the effect of different levels of sodium chloride combined with $\mathrm{Fe}_{2} \mathrm{O}_{3}$ NPs on proline content, Fig (4) indicated that using $\mathrm{Fe}_{2} \mathrm{O}_{3}$ NPs with all salinity levels reduced the proline content which ranged from 0.121 to $0.257 \mathrm{nmol} / \mathrm{mg}$ compared with using $\mathrm{NaCl}$ alone which ranged from 0.151 to $0.451 \mathrm{nmol} / \mathrm{mg}$. However, all treatments raised the content of proline compared to control treatment, except $1000 \mathrm{ppm}$ of $\mathrm{NaCl}$ plus $\mathrm{Fe}_{2} \mathrm{O}_{3} \mathrm{NPs}$ at 5 or $10 \mathrm{mg} / 1$ which gave 0.123 and $0.121 \mathrm{nmol} / \mathrm{mg}$. These results were in agreement with Meheri et al. (2017) on Mentha piperita L. plant. Proline content was enhanced by the increase of $\mathrm{NaCl}$ concentrates as a compatible molecule in the cell, proline plays role in osmotic adjustments, stabilizes sub-cellular structures, and scavenges free radicals. (Tan et al., 2008). 


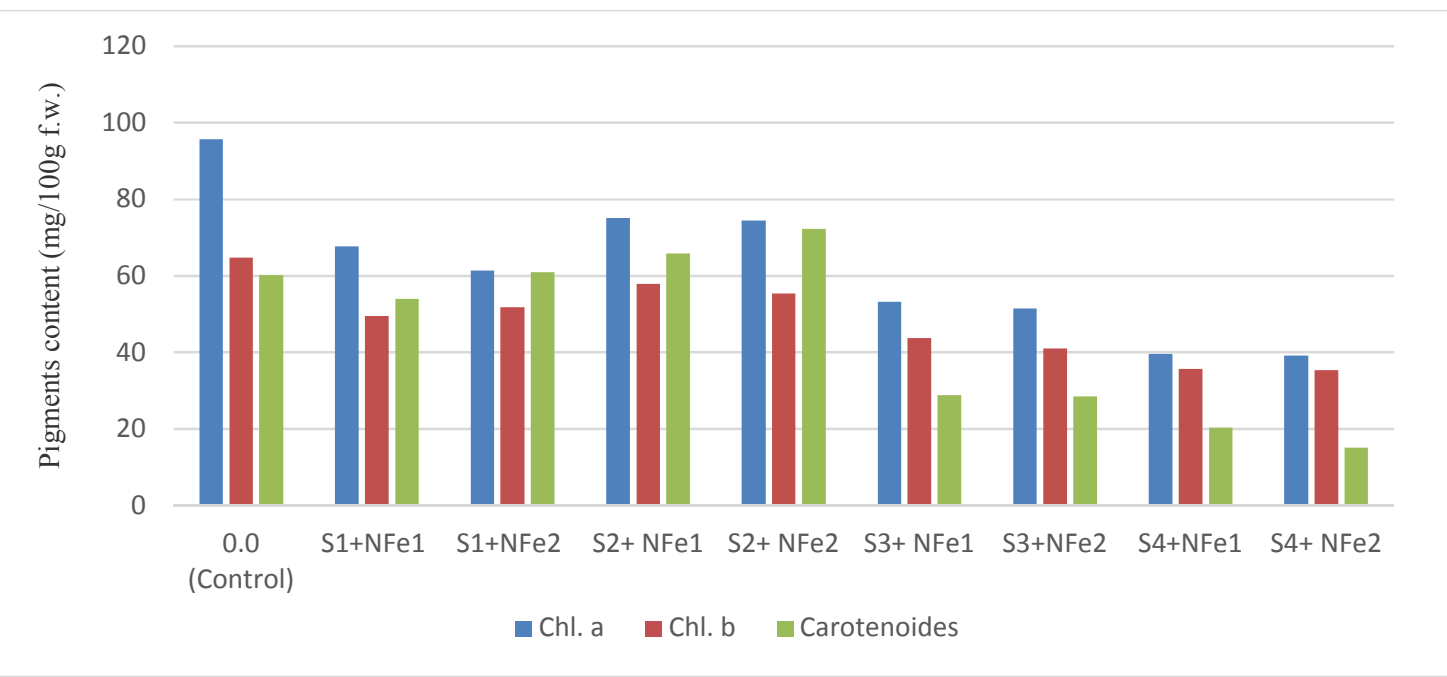

Fig. 2: Photosynthetic pigments content in Populus alba plantlets effecting by different salinity levels and $\mathrm{Fe}_{2} \mathrm{O}_{3} \mathrm{NPs}$ concentration.

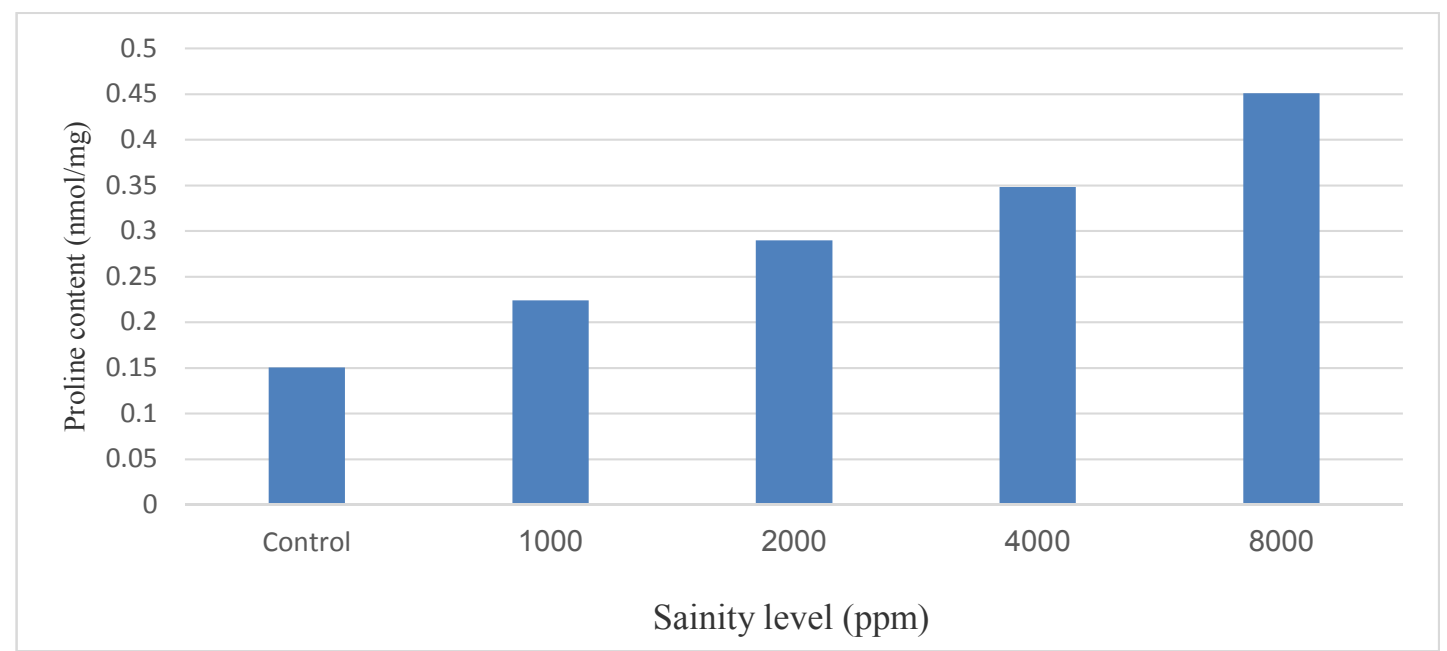

Fig. 3: Proline content in Populus alba plantlets effecting by different salinity levels

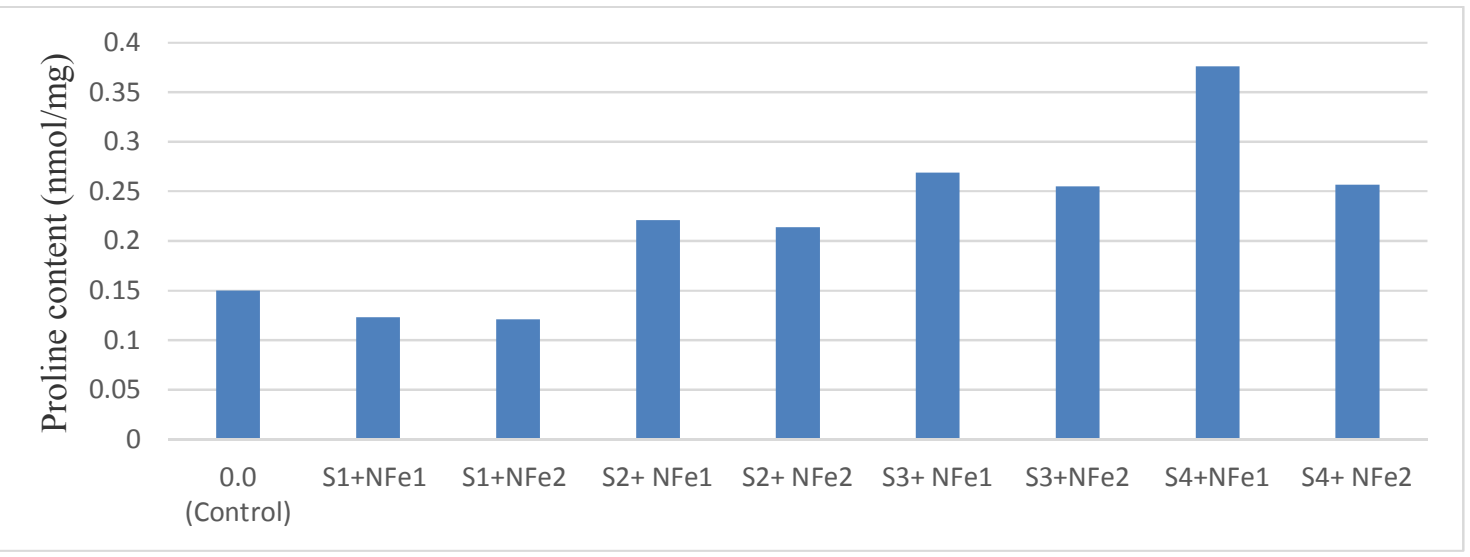

Fig. 4: Proline content in Populus alba plantlets effecting by different salinity levels and $\mathrm{Fe}_{2} \mathrm{O}_{3} \mathrm{NPs}$ 


\section{Conclusion}

Supplementation of $\mathrm{Fe}_{2} \mathrm{O}_{3}$ NPs at $10 \mathrm{mg} / \mathrm{l}$ with 2000 ppm salinity to MS culture medium had significant promotion effect for in vitro shooting parameters compared with other treatments. Addition of $\mathrm{Fe}_{2} \mathrm{O}_{3}$ NPs to culture medium led to increase in the content of chlorophyll a, b and carotenoids compared with using $\mathrm{NaCl}$ alone. Using $\mathrm{Fe}_{2} \mathrm{O}_{3} \mathrm{NPs}$ with all salinity levels reduced the proline content compared with using $\mathrm{NaCl}$ alone.

Populus alba trees tolerate salinity to $4000 \mathrm{ppm}$, but their growth is weak. Its growth is improved by the addition of $\mathrm{Fe}_{2} \mathrm{O}_{3} \mathrm{NPs}$ at $10 \mathrm{mg} / \mathrm{l}$.

\section{References}

Amirnia, R., M. Bayat, and M. Tajbakhsh, 2014. Effects of nano fertilizer application and maternal corm weight on flowering of some saffron (Crocus sativus L.) Ecotypes. Turkish Journal of Field Crops, 19:158-168.

Barberon, M., E. Zelazny, S. Robert, G. Conjero, C. Curic, J. Friml, and G. Ver, 2011. Monoubiquitin-dependent endocytosis of the iron regulated transporter1 (IRT1) transporter controls iron uptake in plants. Proceedings of the National Academy of Sciences of the United States of America Journal (PNAS), 108: 450-458.

Cano, E.A., F. Perez-Alfocea, V. Moreno, M. Caro, and M.C. Bolarin, 1998. Evaluation of salt tolerance in cultivated and wild tomato species through in vitro shoot apex culture. Plant Cell Tiss. Org. Cult., 53: 19-26.

Carillo, P., Y. Gibon, and contributors, 2011. Extraction and determination of proline. In PrometheusWiki available at http://prometheuswiki.publish.csiro.au /tikiindex .php?page $=$ PROTOCOL $\% 3 \mathrm{~A}+$ Extraction + and + determination + of + proline .

Carvajal, M., A. Cerda, and V. Martinez, 2000. Modification of the response of saline stressed tomato plants by the correction of cation disorders. Plant Growth Regulation, 30: 37-47.

Confalonieri, M., B. Belenghi, A. Balestrazzi, S.Negri, G.Facciotto, G.Schenone, and M. Delledonne, 2000. Transformation of elite white poplar (Populus alba L.) cv. "Villafranca" and evaluation of herbicide resistance, Plant Cell Rep., 19: 978-982.

Duncan, D.B., 1955. Multiple range and multiple F-tests. Biometrices, 11:1-42.

El- Sayed, A.A., 2013. Effect of type, fertilization and salinity on growth and constituents of Moringa Oleifera Lam. M. Sc. Thesis, Fac. Agric., Cairo Univ., Egypt, Pp:112.

Fageria, N.K., V.C. Baligar, and R.J. Wright, 1990. Iron nutrition of plants: An overview on the chemistry and physiology of its deficiency and toxicity. Pesquisa Agropecuária Brasileira, 25: 553-570.

Farahat, M.M., 1990. Salinity and drought tolerance of Schinus molle, S. terebinthifolia and Myoporum acuminatum. Ph.D. Thesis Fac. Agri., Cairo University, Egypt.

Fathy, H.M., S.A. Shaaban, and L.S. Taha, 2019. Application of some Nanoparticles on in vitro growth of Populus alba L. plant under salinity stress. Curr. Sci. Int., 8(1): 47-61.

Jalali, M. and M. Zargani, 2014. The impact of nano Fe-chelate, Fe - EDDHA non-nano and FeSO4 on the growth and physiological index in lettuce (Lactuca sativa L.) varieties grown in NFT. Journal of Biodiversity and Environmental Sciences, 4: 434-442.

JamzadFard, M., M. Mousavi, and M.H. GhafarianMogharab, 2013. Investigation on effect of Fe oxide nanoparticles on shoot proliferation and rooting in miniature rose in vitro. The 1st National Conference on Solution to Access Sustainable Development in Agriculture, Natural Resources and Environment, 10 March, Tehran Pp 7.

Karley, A., R. Leigh, and D. Sanders, 2000. Differential ion accumulation and ion fluxes in the mesophyll and epidermis of barley. Journal of Plant Physiology, 122: 835-844.

Koca, M., M. Bor, F. Ozdemir, and I. Turkan, 2007. The effect of salt stress on lipid peroxidation, antioxidative enzymes and proline content of sesame cultivars. Environmental Experimental Botany, 60: 344-351.

Kovacevic, B., S. Orlovic, S. Roncevic, and D. Miladinovic, 2010b. The effect of silver ion, 1napthalene acetic acid and 6-benzylaminopurine on micropropagation of ,Fastgiate "tree shape variety Populus alba cl. LBM, Acta Hort., 885: 197-202. 
Kovacevic, B., Z. Tomovic, D. Stajner, M. Katanic, M. Drekic, and S. Stojnic, 2010a. Restoration of autochthonous poplar species (Populus sp.) in riparian zone - genofond establishment, Topola/Poplar 185/186, (61-68) [In Serbian].

Kuciakowski, R., A.R. Zesz Nauk, and W. Krakowie, 1997. In vitro selection for $\mathrm{NaCl}$ tolerance of Citrus limon nucellar lines. SesjaNauk, 50: 409-411.

Mahmoudi, M., M.A. Shokrgozar, A. Simchi, A. Imani, S. Milani, P. Stroeve, H. Vali, U.O. Hafeli, and S.H. Bonakdar, 2009. Multiphysics flow modeling and in vitro toxicity of iron oxide nanoparticles coated with poly (vinyl alcohol). The Journal of Physical ChemistryiC., 113: 23222331.

Meheri, A., M.T. Sayed, A. Fariba, And D.B.B. Ali, 2017. Effect of iron nanoparticles on Mentha piperita L. Under salinity stress. Biologija, 63(1): 65-75.

Murashige, T. and F. Skoog, 1962. A revised medium for rapid growth and bioassays with tobacco tissue cultures. Bilogia Plantarum, 15: 473-497.

Rawat, J.S. and S.P. Banerjee, 1998. The influence of salinity o growth, biomas production and photosynthesis of Eucalyptus camadulensis, Dehnh. and Dalbergia sissoo Roxb. seedling. Plant and Soil, 205(2):163-169.

Saeedi, S., M. Mousa, and M.H.Gh. Mogharab, 2016. In-vitro analysis of the efficacy of fe oxide nanoparticles in prevention of iron deficiency chlorosis in citrus rootstock (Citrus volkameriana). Journal of Experimental Biology and Agricultural Sciences,4(5):484-492.

Santos, C., 1998. Estudo de alguns mecanismos de regulacŏo osmoticaeda expressao de glutamine sintetase células de. Helianthus annuus L. Snjeitus a sresss alino: Seleccao de celulastolerantes a $\mathrm{NaCl}-\mathrm{Ph}$. D thesis Uni. Aveiro, Portugal.

Siler, B., D. Misic, B. Filipovic, Z. Popovic, T. Cvetic and A. Mijovic, 2007. Effect of salinity stress on growth and photosynthesis of Common Centaury (Centaurium erythraea). Arch. Biol. Sci. Belgrade, 59: 129-134.

Sivanesan, L., S.L. Hwang, and B.R. Jeong, 2008. Influence of plant growth regulators on axillary shoot multiplication and iron source on growth of Scrophularia takesimensis Nakal- a rare endemic medicinal plant. Afr. Biotechnology, 7(24): 4484-4490.

Tan, J., H.Zhao, J.Hong, Y.Han, H. Li, and W. Zhao, 2008. Effect of exogenous nitric oxide on photosynthesis, antioxidant capacity and proline accumulation in wheat seedlings subjected to osmotic stress. World J. Agric. Sci. 4: 307-311.

Vera-Estrella, R., B. Barkla, H. Bohnert, and O. Pantoja, 2004. Novel regulation of aquaporins during osmotic stress. Journal of Plant Physiology, 135: 2318-2329.

Wahome, P.K., H.H.Jesh, and P.Ghosh, 2001. Effect of sodium chloride stress on Rosa plants growing in vitro. Sci. Hortic., 90: 187-191.

Waruna Jinadasa, R.G., 2013. Design, synthesis, and characterization of porphyrin derivatives for biological applications. Ph.D. Thesis submitted to Department of Chemistry, Agricultural and Mechanical College, Louisiana State University. Pp: 246.

Yang, C.M., K.W.Chang, M.H. Yin and H.M. Huang, 1998. Methods for the determination of the chlorophylls and their derivatives. Taiwania, 43(2): 116-122. 